\title{
Marthamyces manglicola, a new species (Ascomycota, Marthamycetaceae) on black mangrove from Cozumel Island, Mexico
}

\section{Marthamyces manglicola, una especie nueva (Ascomycota, Marthamycetaceae) sobre mangle negro de la Isla de Cozumel, México} Acta Botanica Mexicana

\author{
Tania Raymundo' (D), Yenitze García-Martínez² (D), Michelle Martínez-Pinedal (iD, Ricardo Valenzuela’,3 (iD)
}

\begin{abstract}
:
Background and Aims: The genus Marthamyces is characterized by its orbicular to polygonal apothecia, immersed within the host tissue, erumpent from the substrate surface, by the hymenium with pruinose appearance due to the presence of small crystals on its surface and amongst the paraphyses, and by filiform, 0 - to 3-septate ascospores. Members of this genus grow on leaves of plants throughout the world, mainly in the tropics and subtropics. The aims of this study are to describe and illustrate Marthamyces manglicola as a new species that grows on Avicennia germinans (black mangrove) from Cozumel Island and to elaborate a key to all species of the genus Marthamyces described until now.

Methods: Specimens were collected on fallen leaves of black mangrove in Punta Sur Ecological Park, Cozumel Island Biosphere Reserve. Field data and morphological characteristics were recorded using the traditional techniques in mycology. The material was deposited in the ENCB herbarium of the Escuela Nacional de Ciencias Biológicas of the Instituto Politécnico Nacional.

Key results: Marthamyces manglicola is characterized by its apothecia opening by 3-5 pruinose and yellowish white to pale yellow flaps, a hymenial surface greyish blue to dull blue in young specimens, fading to bluish white to pale blue or pale yellow in mature apothecia. Microscopically, it has paraphyses swelling slightly near the apex, with several short, finger-like projections and straight to slightly curved ascospores on release. A key to all described species of Marthamyces is presented.
\end{abstract}

Conclusions: Marthamyces manglicola on Avicennia germinans (black mangrove) is the only species of this genus described from mangroves.

Key words: Avicennia germinans, Chaetomellales, Leotiomycetes, Mexican Caribbean.

\section{Resumen:}

Antecedentes y Objetivos: El género Marthamyces se caracteriza por sus apotecios orbiculares a poligonales inmersos en el tejido del hospedero y errumpentes en la superficie del sustrato, por el himenio con apariencia pruinosa debido a la presencia de cristales sobre su superficie himenial y entre las paráfisis, y por las ascosporas filiformes, con 0 a 3 septos. Miembros de este género crecen sobre hojas de plantas en todo el mundo, principalmente en los trópicos y subtrópicos. Los objetivos de este estudio son describir e ilustrar a Marthamyces manglicola como especie nueva que crece sobre Avicennia germinans (mangle negro) de la Isla de Cozumel y elaborar una clave de todas las especies del género Marthamyces descritas hasta el momento.

Métodos: Los especímenes fueron recolectados en hojas caídas de mangle negro en el Parque Ecológico Punta Sur de la Reserva de la Biosfera Isla Cozumel. Los datos de campo y las características morfológicas fueron registrados usando las técnicas tradicionales en micología. El material fue depositado en el herbario ENCB de la Escuela Nacional de Ciencias Biológicas del Instituto Politécnico Nacional.

Resultados clave: Marthamyces manglicola se caracteriza por sus apotecios que abren en 3-5 solapas pruinosas, variando en coloración de blancoamarillentos a amarillo pálidos, una superficie himenial azul-grisácea a azul opaca en especímenes jóvenes, decolorando de blanco-azulado a azul pálido o amarillo pálido en apotecios maduros. Microscópicamente, este tiene paráfisis ligeramente ensanchadas cerca del ápice, con varias proyecciones cortas semejantes a dedos y ascosporas rectas a ligeramente curvadas. Se presenta una clave para todas las especies descritas de Marthamyces. Conclusiones: Marthamyces manglicola crece sobre Avicennia germinans (mangle negro) y es la única especie de este género descrita de manglares. Palabras clave: Avicennia germinans, Caribe mexicano, Chaetomellales, Leotiomycetes.

${ }^{1}$ Instituto Politécnico Nacional, Escuela Nacional de Ciencias Biológicas, Laboratorio de Micología, Prolongación de Carpio y Plan de Ayala, Santo Tomás, Alcaldía Miguel Hidalgo, 11340 Cd. Mx., Mexico.

${ }^{2}$ Instituto Politécnico Nacional, Escuela Nacional de Ciencias Biológicas, Posgrado en Biociencias, Prolongación de Carpio y Plan de Ayala, Santo Tomás, Alcaldía Miguel Hidalgo, 11340 Cd. Mx., Mexico.

${ }^{3}$ Author for correspodence: rvalenzg@ipn.mx
Received: June 1, 2021.

Reviewed: August 5, 2021.

Accepted by Rosario Redonda-Martínez: December 16, 2021.

Published Online first: January 24, 2022.

Published: Acta Botanica Mexicana 129 (2022).

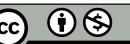

This is an open access article under the Creative Commons 4.0 Attribution -Non commercial Licence (CC BY-NC 4.0 International)
To cite as: T. Raymundo, Y. García-Martínez, M. Martínez-Pineda and R. Valenzuela. 2022. Marthamyces manglicola, a new species (Ascomycota, Marthamycetaceae) on black mangrove from Cozumel Island, México. Acta Botanica Mexicana 129: e1903. DOI: https://doi.org/10.21829/abm129.2022.1903 


\section{Introduction}

Marthamyces was described by Minter (2003) with $M$. emarginatus (Cooke \& Massee) Minter as the type species. It was set up to accommodate species with filiform ascospores placed in Propolis (Fr.) Corda sensu Sherwood (1977) and growing on dead leaves. Marthamyces includes species with ascomata on abaxial and adaxial surface of plants throughout the world, but mainly in the tropics and subtropics (Johnston, 2006). Macroscopically, apothecia are subepidermal, orbicular to polygonal, resembling small pustules, erumpent from the substrate surface, not associated with bleaching of surrounding substrate, and lacking associated zone lines (Minter, 2003; Johnston, 2006). They are deeply immersed within the host tissue, and the surface of the hymenium often has a pruinose appearance due to the presence of small crystals amongst the paraphyses (Johnston, 2006). Microscopically, ascospores are filiform, 0 - to 3-septate, with apical and basal gelatinous caps and the paraphyses have short branches near apex, tapering or swelling, tangled or with several short, finger-like projections, either often intermixed with crystals, or coated with crystals, the tips of the paraphyses sometimes being embedded in brownish gel (Sherwood, 1977; Johnston, 2006). Marthamyces is the type genus of the family Marthamycetaceae, order Chaetomellales, class Leotiomycetes of the phylum Ascomycota (Ekanayaka et al., 2019).

The genus Marthamyces has 18 described species. Of these, 13 species are registered from Australia and New Zealand, five from the Americas, three from Europe, two from Asia and one from Africa. Only two have previously been reported from Mexico, Marthamyces quadrifidus (Lév.) Minter (as Propolis quadrifida (Lev.) Mont.) from Oaxaca (Sherwood, 1977), and M. coronadoae Raymundo, R. Valenz. \& Esqueda described on Fagus grandifolia Ehrh. subsp. mexicana (Martínez) A.E. Murray in the municipality of Zacualtipán, Hidalgo state (Raymundo et al., 2016). In 2019, during a visit to the Cozumel Island Biosphere Reserve, several fallen leaves of Avicennia germinans (L.) L. (black mangrove) were collected in the Punta Sur Ecological Park in mangroves. They had small pustules of erumpent apothecia of a fungus which did not correspond to any known species. The aims of this study are to describe and illustrate Marthamyces manglicola as a new species that grows on Avicennia germinans (black mangrove) on Cozumel Island and to elaborate a key to all species of the genus.

\section{Materials and Methods}

Punta Sur Ecological Park, located in the Cozumel Island Biosphere Reserve, Quintana Roo, Mexico, has an area of 1114 ha, with coastal dunes and mangroves as a principal type of vegetation (Fig. 1). Dominant plant species are Rhizophora mangle L. (Rhizophoraceae), Laguncularia racemosa (L.) C.F. Gaertn. (Combretaceae), Conocarpus erectus L. (Combretaceae) and Avicennia germinans (Acanthaceae).

Our specimens are deposited in the Herbarium ENCB of the Escuela Nacional de Ciencias Biológicas, Instituto Politécnico Nacional, Mexico City, Mexico. Longitude and latitude coordinates were obtained with GPS eTrex (Garmin, Olathe, USA). Colors were coded according to Kornerup and Wanscher (1978). Morphological examinations were conducted using protocols outlined by Johnston (2006) and Raymundo et al. (2016). Measurements of anatomical characters were taken from rehydrated tissues in 5\% aqueous $\mathrm{KOH}$ and Melzer's reagent with camera optical microscope (CX-31, Olympus, Tokyo, Japan). The macroscopic pictures were taken with a Nikon D7000 (Nikon, Tokyo, Japan) and the microscopic pictures with a Sony DSC-WX350 (Nikon, Tokyo, Japan). The morphological terms are based on the dictionary of Ulloa and Hanlin (2012).

A key of all described species to the genus Marthamyces is presented as a tool to differentiate the new species from the other species. The identification key can be applied globally given the broad distribution of the host (Avicennia L.) in different parts of the world. The following literature was used to elaborate this key: De Notaris (1845), Sherwood (1977), Johnston (1986, 1991, 2006), Gu et al. (2015), Raymundo et al. (2016), Crous et al. (2019), Johnston and Park (2019).

\section{Results}

\section{Taxonomy}

Ascomycota 


\section{Letiomycetes}

\section{Chaetomellales}

\section{Marthamycetaceae}

Marthamyces manglicola Raymundo, García-Martínez,

Martínez-Pineda \& R. Valenz., sp. nov. Figs. 2, 3.

TYPE: MEXICO. Quintana Roo, municipio Cozumel, Reserva de la Biosfera Isla de Cozumel, Parque Ecológico Punta Sur, $28^{\circ} 16^{\prime} 48^{\prime \prime} \mathrm{N}, 86^{\circ} 58^{\prime} 44.39^{\prime \prime} \mathrm{W}, 16 . X .2019$, T. Raymundo 8324 (holotype: ENCB!); Mycobank: MB839088.

Marthamyces manglicola differs from $M$. quadrifidus in having apothecia opening by 3-5 pruinose and yellowish white to pale yellow flaps, a hymenial surface greyish blue to dull blue in young specimens, fading to bluish white to pale blue or pale yellow in mature apothecia; paraphyses swelling slightly near apex, with several short, finger-like projections and ascospores 50-60 × 1-2.4 $\mu \mathrm{m}$, straight to slightly curved, hyaline, 0 - to 1 -septate.

Apothecia 0.7-1 mm diameter, on abaxial and adaxial surfaces of dead leaves, subepidermal, resembling small pustules, visible initially as round brown patches on the leaf surface, becoming raised as ascomata mature, erumpent from the substrate surface, not associated with bleaching of host tissue, without zone lines, polygonal, some triangular, quadrangular to rhomboid, others irregular in shape, superficial layer brown to beige in young apothecia, covering the hymenium, opening by 3-5 prominent, irregu-

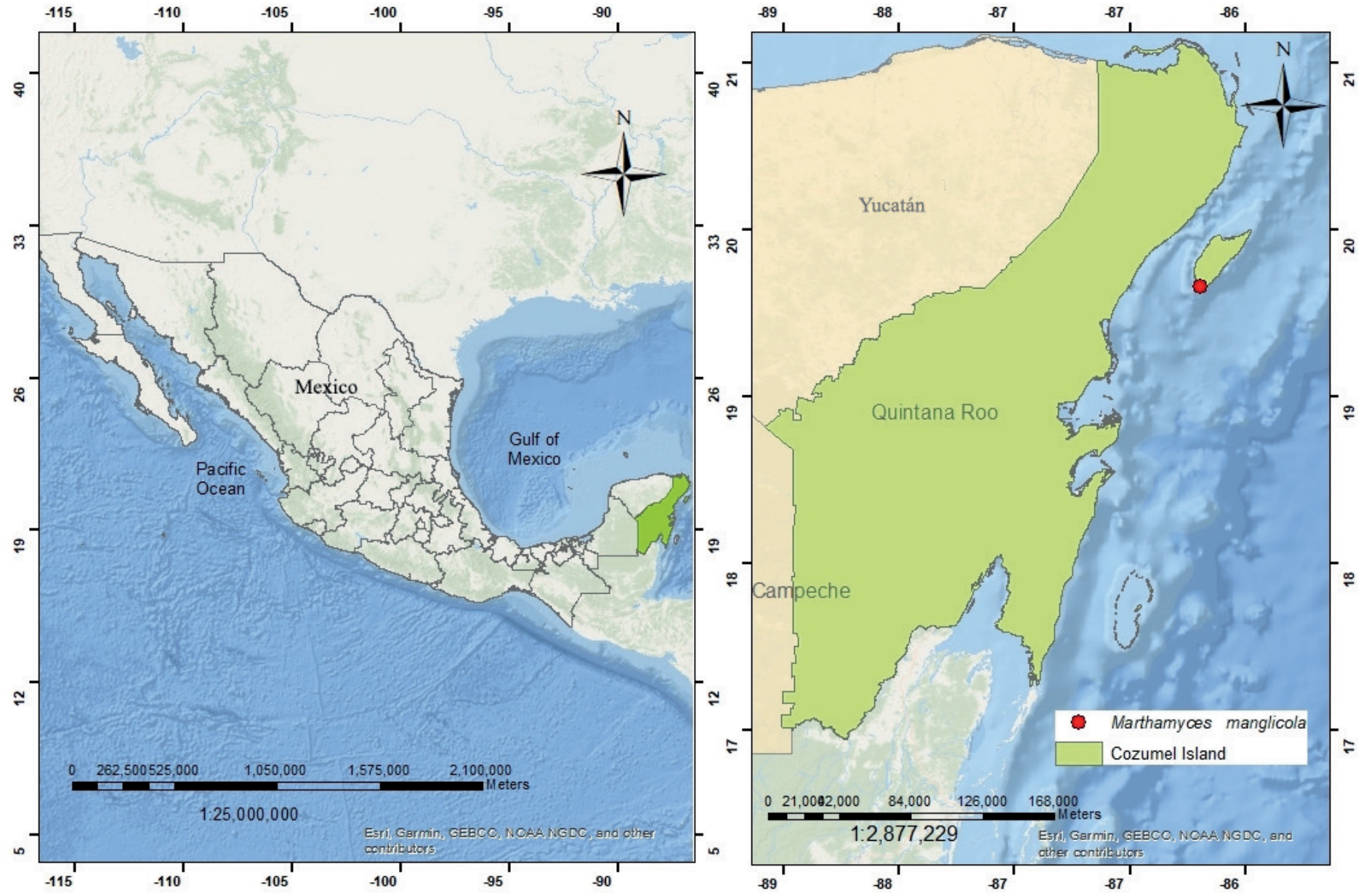

Figure 1: Map of the locality of Marthamyces manglicola Raymundo, García-Martínez, Martínez-Pineda \& R. Valenz. 

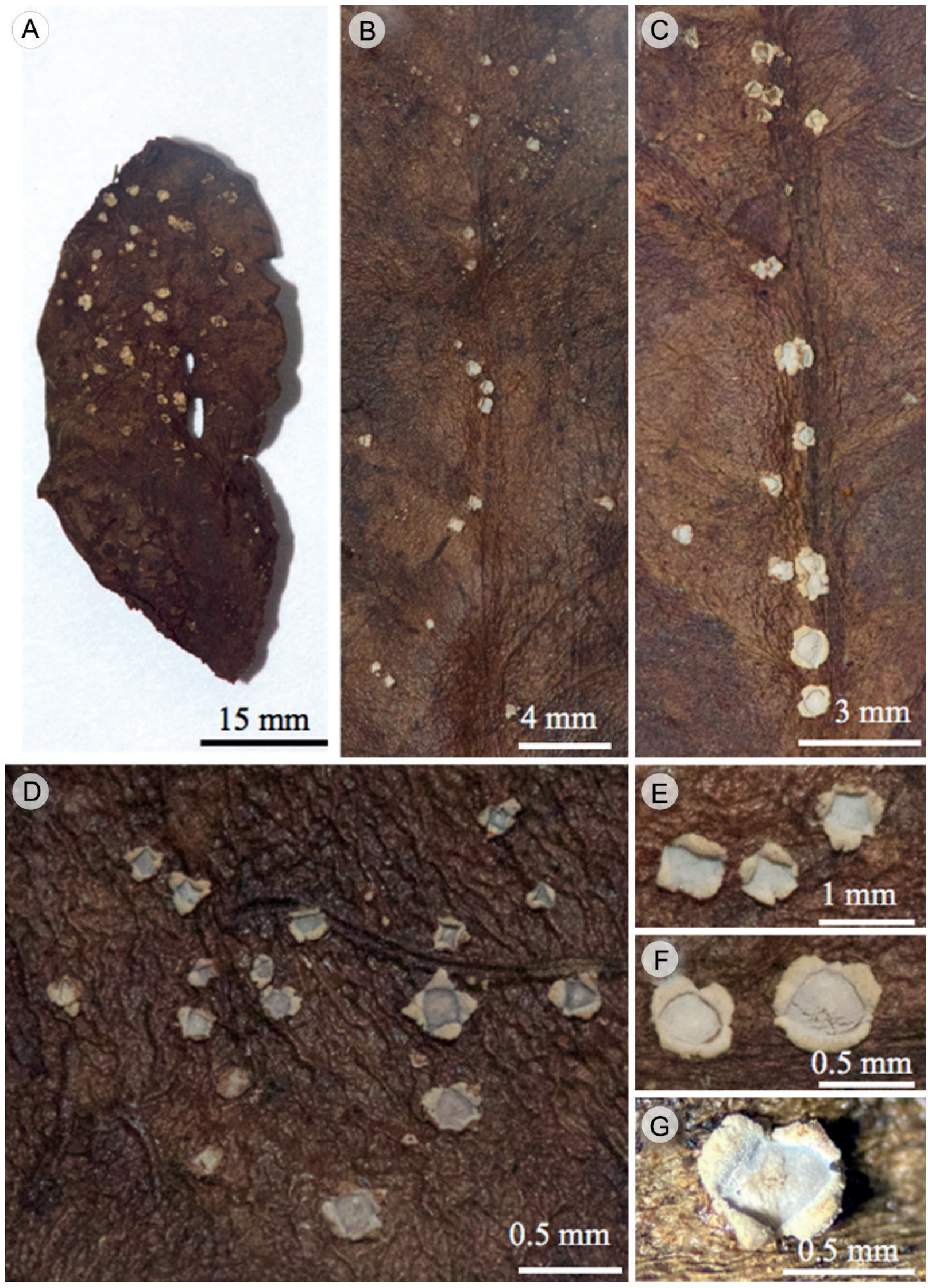

Figure 2: Marthamyces manglicola Raymundo, García-Martínez, Martínez-Pineda \& R. Valenz. A. ascomata growing on leaves of Avicennia germinans L.; B. gregarious apothecia on abaxial surface; C. gregarious apothecia on adaxial surface; D. apothecia with exposed hymenium; E. polygonal hypothecia; F. quadrangular and triangular apothecia; G. pruinose hymenium. 
lar, pruinose and yellowish white (4A2) to pale yellow (4A3) flaps; hymenium somewhat depressed below level of the substrate, pruinose, greyish blue (22B4) to dull blue (22D5) in young specimens, fading to bluish white $(22 \mathrm{~A} 2)$ to pale blue (22A3) or pale yellow (4A3) in several parts of mature apothecia, perimeter line absent; paraphyses up to $90 \mu \mathrm{m}$ long and $2 \mu \mathrm{m}$ diameter, swelling slightly near apex, up to $3 \mu \mathrm{m}$ diameter, with several short, finger-like projections, coated with crystals at the apex, crystals soluble in $\mathrm{KOH}$; asci $65-80 \times 6-8 \mu \mathrm{m}$, subcylindric to subfusoid, tapering at apex, wall undifferentiated at the apex, 8-spored; ascospores parallel to subparallel in the ascus, 50-60 × 1-2.4 $\mu \mathrm{m}$, filiform, straight to slightly curved on release, colorless in $\mathrm{KOH}$, thin walled, 0- to 1-septate, apical and basal gelatinous caps, globose, 2-2.5 $\mu \mathrm{m}$ diameter, gelatinous caps soluble in $\mathrm{KOH}$.

Habit and habitat: growing on fresh fallen leaves and dead leaves of Avicennia germinans in mangrove forest.

Etymology: referring to the common name in Spanish (manglar) of habitat where the species is growing.

Additional material examined: MEXICO. Quintana Roo, municipio Cozumel, Reserva de la Biosfera Isla de Cozumel, Parque Ecológico Punta Sur, 28 $16^{\prime} 48^{\prime \prime} \mathrm{N}$, $86^{\circ} 58^{\prime} 44.39$ 'W, 16.X.2019, T. Raymundo 8323 (ENCB), 8338 (ENCB), 8341 (ENCB).

Taxonomy notes: Marthamyces manglicola is characterized by its polygonal to irregular apothecia, the young apothecia erumpent from a brown covering layer, opening by 3-5 prominent irregular and yellowish white to pale yellow flaps, and by its straight to slightly curved on release and 0 - to 1-septate ascospores.

Key to the world species of Marthamyces based on literature

1a. Apothecia growing on several Monocots: Carex L. and Ficinia Schrad. (Cyperaceae), Dendrobium Sw. (Orchidaceae), Andropogon L. and Panicum Lam. (Poaceae), Phormium J.R. Forst. \& G. Forst (Xanthorrhoeaceae) ... 1b. Apothecia growing on several Eudicots and some Magnoliids: Avicennia L. (Asterides, Acanthaceae), Aetoxicum Ruiz \& Pav. (Superasterids, Aetoxicaceae), Fissistigma Griff. (Magnoliids, Annonaceae), Arctostaphylos Adans. (Asterids, Ericaceae), Fagus L. and Quercus L. (Rosids, Fagaceae), Eucalyptus L' Hér. and Metrosideros Banks ex Gaertn. (Rosids, Myrtaceae), Olea L. (Asterids, Oleaceae), Hakea Schrad. and Orites R. Br. (Eudicots, Proteaceae) 6

2a. Apothecia opening by single longitudinal slits

Marthamyces desmoschoeni (P.R. Johnst.) Minter 2b. Apothecia opening in several radial or irregular slits ... 3 3a. Only growing on Carex firma Host. from Austria Marthamyces foliicola Nograsek \& Matzer

3b. Species growing on Andropogon, Dendrobium, Panicum or Phormium 4

4a. Apothecia round, opening by radial slits, growing on Dendrobium from New Zealand

Marthamyces dendrobi (P. R. Johnst.) Minter

4b. Apothecia not round, opening by irregular slits, growing on Andropogon, Panicum or Phormium from USA and New Zealand 5

5a. Apothecia narrow elliptical to elongate, no flaps ruptured, hymenium pale blue, 37-42 × 2-3 $\mu \mathrm{m}$, 1-septate, straight, on Andropogon and Panicum from USA ...... Marthamyces culmigenus (Ellis \& Langlois) P. R. Johnst. $5 b$. Apothecia irregular in shape, splitting irregularly, flaps not defined, hymenium pale yellow to greenish yellow, ascospores $55-78 \times 3.5-4.5 \mu \mathrm{m}$, 1-septate, straight to slightly curved, on Phormium tenax J. R. Forst. \& G. Forst. from New Zealand

Marthamyces harakeke P.R. Johnst.

6a. Ascospores 0- to 1-septate ............................................... 7

6b. Ascospores 3- to 5-septate ........................................... 16

7a. Ascospores straight to slightly curved ............................. 8

7b. Ascospores curved, sigmoid or coiled 14

8a. Paraphyses simple, not branched, becoming clavate Marthamyces johntonii Crous \& Carnegie

8b. Paraphyses branched at the apex ................................... 9

9a. Paraphyses swelling near the apex, with several short finger-like projections 10

9b. Paraphyses tapering toward the apex, with several short narrow branches at apex 11 

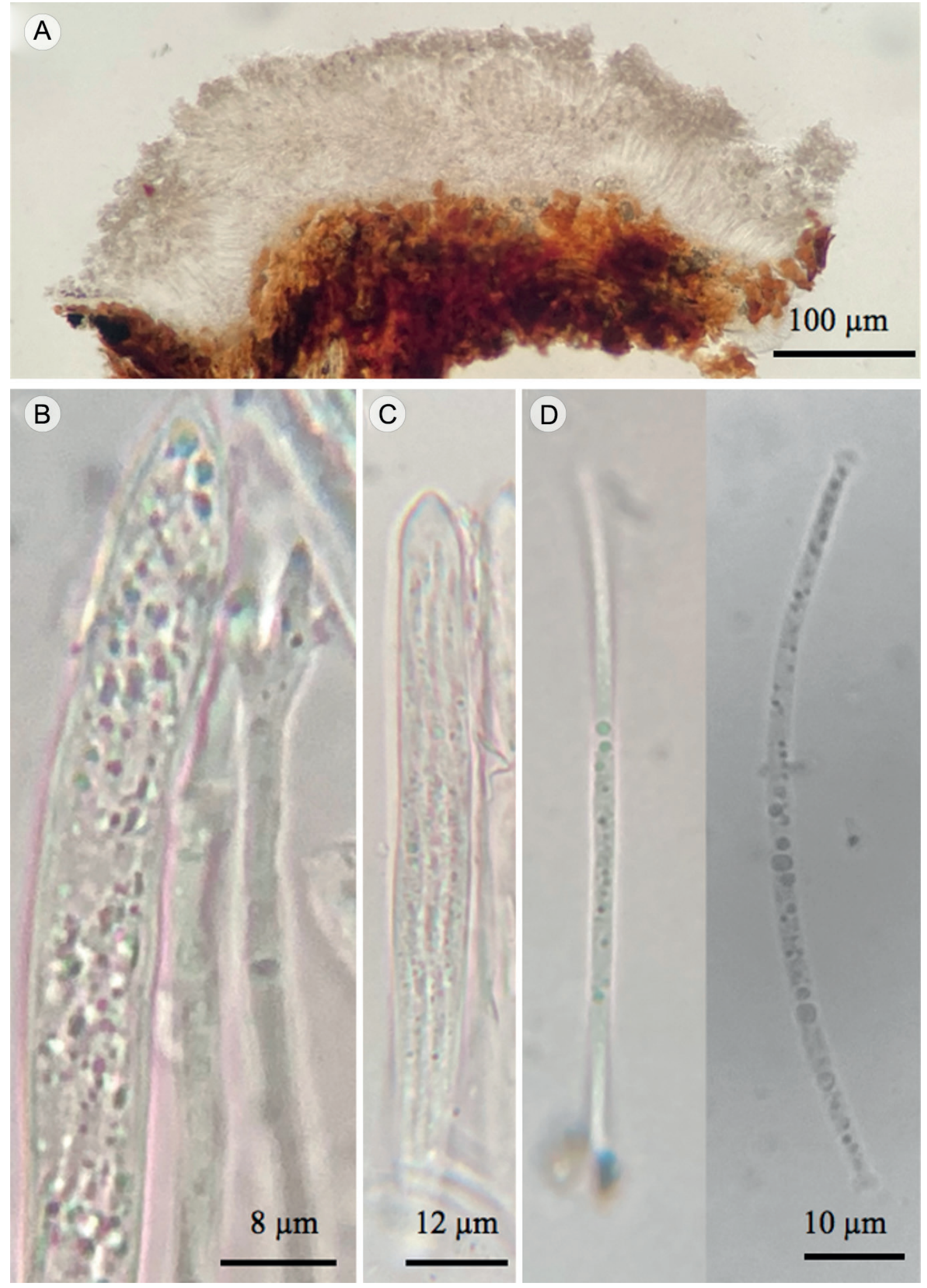

Figure 3: Marthamyces manglicola Raymundo, García-Martínez, Martínez-Pineda \& R. Valenz. A. apothecium; B. asci and paraphyse apex; C. asci; D. ascospores. 
10a. Apothecia round to irregular, hymenium dark green, without crystals, opening by 2-3 irregular white flaps, ascospores $(65-) 75-85(-90) \times 2-2.5 \mu \mathrm{m}$, on Orites acicularis (R. Br.) Roem. \& Schult. from Tasmania Marthamyces oritis P.R. Johnst.

10b. Apothecia polygonal to irregular, hymenium bluish white to pale blue, pruinose by the crystals, opening by $3-5$ yellowish white to pale yellow flaps, ascospores 50-60 × 1-2.4 $\mu \mathrm{m}$, on Avicennia germinans L. from Mexico Marthamyces manglicola Raymundo, García-Martínez, Martínez-Pineda \& R. Valenz.

11a. Growing on Eucalyptus L. Her., flaps dark brown, 3-5 in the apothecia

.... Marthamyces emarginatus (Cooke \& Massee) Minter

11b. Growing on Metrosideros, flaps white to pale yellow, (2-)3-4(-5) in the apothecia 12

12a. Apothecia angular to elongate Marthamyces renga P. R. Johnst.

12b. Apothecia orbicular to angular, not elongate 13

13a. Hymenium white, ascospores 45-85 $\times$ 2-3 $\mu \mathrm{m}$, growing on $M$. robusta A. Cunn. from New Zealand Marthamyces metrosideri P. R. Johnst.

$13 b$. Hymenium pale yellow to grey, ascospores 50-70 $\times 1.5-$ $2 \mu \mathrm{m}$, growing on M. collina (J. R. Forst. \& G. Forst.) A. Gray from the Cook Islands

Marthamyces maccormackii P. R. Johnst.

14a. Ascospores (95-)110-135(-160) × 2-2.5 $\mu \mathrm{m}$

Marthamyces hakeae P. R. Johnst.

14b. Ascospores 60-74(-80) × 1.2-2.4 $\mu \mathrm{m}$ 15

15a. Apothecia triangular to pentagonal, occasionally elliptical, hymenium white, opening by 3-5 grey flaps, ascospores 60-72 × 1.2-1.6 $\mu \mathrm{m}$, on Fissistigma from China Marthamyces chinensis Y. R. Lin \& H. L. Gu

15b. Apothecia orbicular to polygonal, opening by $4-5$ brownish beige flaps, hymenium pale grey to pale yellow, ascospores 60-74(-80) $\times$ 1.6-2.4 $\mu \mathrm{m}$, on Fagus grandifolia subsp. mexicana from Mexico ....... Marthamyces coronadoae Raymundo, R. Valenz. \& Esqueda

16a. Ascospores 5-septate, 75-105 × 2.5-3 $\mu \mathrm{m}$, on Olea from Italy Marthamyces panizzei (De Not.) Minter

16b. Ascospores 3-septate, 50-75 × $1.5 \mu \mathrm{m}$, on Aetoxicum, Arctostaphylos and Quercus from Chile, Sweden and USA 17 17a. Apothecia angular, hymenium pale gray Marthamyces quadrifidus (Lev) Minter 17b. Apothecia orbicular, hymenium white to pale yellow 18

18a. Growing on Quercus, ascospores 50-65 × $1.5 \mu \mathrm{m}$ Marthamyces quercifolius (Cooke \& Ellis) Minter 18b. Growing on Arctostaphylos uva-ursi (L.) Spreng., ascospores $60-75 \times 1.5-2.0 \mu \mathrm{m}$

Marthamyces phacidioides (Fr.) Minter

\section{Discussion}

The principal features that can distinguish species of Marthamyces are color and presence of pruinose material in flaps of the ascomata, color of the hymenial surface and size, shape and number of septa of ascospores. In addition, we consider that the plant with which each Marthamyces species is associated can be an important ecological character to separate species. Besides, other authors who have described species of Marthamyces have found a narrow range of hosts (Gu et al., 2015; Raymundo et al., 2016; Johnston and Park, 2019). Marthamyces coronadoae and M. emarginatus are close to M. manglicola by having 0 - to 1-septate ascospores but differ by ascospore size and associated plant identity; the first species has larger ascospores $(60-75 \times 1.6-2.4 \mu \mathrm{m})$ and grows on Fagus L. (Raymundo et al., 2016), while in the second ascospores are (60-)65$75(-85) \times 2(-2.5) \mu \mathrm{m}$ and the fungus grows on Eucalyptus (Sherwood, 1977; Johnston, 2006). Other American species are M. phacidioides (Fr.) Minter, M. quercifolius (Cooke \& Ellis) Minter and M. quadrifidus, but they are separated by 3-septate and larger ascospores (Sherwood, 1977; Cabarroi-Hernández et al., 2014).

Species of Marthamyces have been quoted as biotrophs (Gu et al., 2015; Johnston and Park, 2019) and saprobes (Minter, 2003; Raymundo et al., 2016) and always as foliicolous fungi. Ascomata of Marthamyces manglicola were found on freshly fallen leaves. Hyde and Soytong (2008), Promputtha et al. (2010) and De Silva et al. (2016) suggest that this is evidence of an endophytic life strategy, growing on living leaves, followed by the production of sporophores as saprobes after leaf death, during decomposition. For mangroves this process is very important because they generate a large amount of litter which fungi 
can decompose into simpler organic matter which is then exported to the neighboring ecosystem such as seagrasses and coral reefs.

Another important aspect is the host identity of the associated plant. Marthamyces species show a preference for colonizing particular plants (Johnston and Park, 2019). Although M. manglicola was found in a mangrove forest with four mangrove species: Avicennia germinans, Rhizophora mangle L., Laguncularia racemosa C.F.Gaertn. and Conocarpus erectus L. (Téllez-Valdés et al., 1989), it was found only on A. germinans. The factors likely to determine host specificityare physicochemical characteristics of the leaves, such as the amount of tannins, degree of lignification and the presence of salt. Compared with other mangrove species, $A$. germinans is known to have less tannins than $R$. mangle and more salt than the other taxa mentioned, due to its ability to exclude salt through leaf glands (Clough, 2013). Marthamyces manglicola can therefore be considered a halotolerant and able to tolerate conditions particular to mangrove forest such as waterlogging and high solar radiation.

\section{Conclusions}

Most Marthamyces species have been reported from temperate and tropical forest (Minter, 2003; Johnston and Park, 2019). Marthamyces manglicola is the first species of this genus found in mangrove ecosystems, and is manglicolous. This is important because only around 300 species of manglicolous fungi are known globally (Raghukumar, 2017). Marthamyces manglicola is presented as a new species growing on fresh fallen and dead leaves of Avicennia germinans in mangrove forests in Cozumel Island.

\section{Author contributions}

TR and RV conceived and designed the study. TR carried out the collections and TR, RV, YAGM and MMP made the determinations of the species. The photos of the figures were taken by TR. TR y RV drafted the manuscript with the help of MMP and YAGM. All authors contributed to the discussion, review, and approval of the final manuscript.

\section{Funding}

This study was supported by the Instituto Politécnico Nacional with the project (SIP): 20220030, 20221348 and the
Consejo Nacional de Ciencia y Tecnología through basic science project 252934.

\section{Acknowledgements}

The authors express their gratitude to the authorities of the Protected Natural Areas for the facilities granted to carry out this study: Emilio Villanueva Sosa (Director Fundación parques y museos de Cozumel) and José de Jesús Benavides Andrade (Director de Punta Sur).

\section{Literature cited}

Cabarroi-Hernández, M., P. R. Johnston and D. W. Minter. 2014. Rhytismataceae (Ascomycota) in Cuba. Willdenowia 44: 6575. DOI: http://doi.org/10.3372/wi.44.44110

Clough, B. 2013. Continuing the Journey Amongst Mangroves. Mangrove Educational Book. Series No. 1, International Society for Mangrove Ecosystems (ISME) International Tropical Timber Organization (ITTO). Okinawa, Japan. 72 pp.

Crous, P. W., M. J. Wingfield, R. Cheewangkoon, A. J. Carnegie, T. I. Burgess, B. A. Summerell, J. Edwards, P. W. J. Taylor and J. Z. Groenewald. 2019. Foliar pathogens of eucalypts. Studies in Mycology 94: 125-298. DOI:

De Notaris, J. 1845. Micromycetes Italicy. Novi, vel minus cogniti. Memorie della Reale Accademia delle Scienze di Torino Serie 2(7): 17-29.

De Silva, N. I., S. Lumyong, K. D. Hyde, T. Bulgakov, A. J. L. Phillips and J. Y. Yan. 2016. Mycosphere essays 9: defining biotrophs and hemibiotrophs. Mycosphere 7(5): 545-559. DOI: https://doi.org/10.5943/mycosphere/7/5/2

Ekanayaka, H. A., K. D. Hyde, E. Gentekaki, E. McKenzi, Q. Zhao, T. S. Bulgakov and E. Camporesi. 2019. Preliminary classification of Leotiomycetes. Mycosphere 10(1): 310489. DOI: https://doi.org/10.5943/mycosphere/10/1/7

Gu, H. L., Y. R. Lin, F. Peng, Q. Li and S. J. Wang. 2015. Marthamyces chinensis sp. nov. on Fissistigma from China. Mycotaxon 130(3): 815-820. DOI: https://doi.org/10.5248/130.815

Hyde, K. D. and K. Soytong. 2008. The fungal endophyte dilema. Fungal Diversity 33: 163-173.

Johnston, P. R. 1986. Rhytismataceae in New Zealand 1. Some foliicolous species of Coccomyces de Notaris and Propolis (Fries) Corda. New Zealand Journal of Botany 24(1): 89-124. DOI: https://doi.org/10.1080/0028825X.1986.10409723 
Johnston, P. R. 1991. Rhytismataceae in New Zealand 4. Pureke zelandicum gen. and sp. nov. plus additional species in Hypoderma, Lophodermium, and Propolis. New Zealand Journal of Botany 29(4): 395-404. DOI: https://doi.org/10. 1080/0028825X.1991.10415492

Johnston, P. R. 2006. Rhytismatales of Australia: the genus Marthamyces. Australian Systematic Botany 19(2): 135146. DOI: https://doi.org/10.1071/SB05010

Johnston, P. R. and D. Park. 2019. New species of Marthamyces and Ramomarthamyces gen. nov. from New Zealand and the Cook Islands. Mycotaxon 134(3): 489-516. DOI: https:// doi.org/10.5248/134.489

Kornerup, A. and J. H. Wanscher. 1978. Methuen handbook of colour. 3th ed. Eyre Methuen. London, UK. 225 pp.

Minter, D. W. 2003. Propolis and Marthamyces gen. nov. (Rhytismatales). Mycotaxon 87: 43-52.

Promputtha, I., K. D. Hyde, E. H. C. McKenzie, J. F. Peberdy and S. Lumyong. 2010. Can leaf degrading enzymes provide evidence that endophytic fungi becoming saprobes? Fungal Diversity 41: 89-99. DOI: https://doi.org/10.1007/s13225010-0024-6
Raghukumar, S. 2017. Fungi: Characteristics and Classification. In: Fungi in Coastal and Oceanic marine Ecosystems: Marine Fungi. Springer. Cham, Switzerland. Pp. 1-36. DOI: https:// doi.org/10.1007/978-3-319-54304-8_1

Raymundo, T. R. Valenzuela and M. Esqueda. 2016. Marthamyces coronadoae sp. nov. in a Fagus grandifolia subsp. mexicana forest from Hidalgo State, México. Mycotaxon 131(3): $521-$ 526. DOI: https://doi.org/10.5248/131.521

Sherwood, M. A. 1977. Taxonomic studies in the Phacidiales: Propolis and Propomyces. Mycotaxon 5: 320-330.

Téllez-Valdés, O., E. Cabrera-Cano, E. Linares and R. Bye. 1989. Las plantas de Cozumel. Guía botánico-turística de la Isla Cozumel, Quintana Roo, México. Instituto de Biología, Universidad Nacional Autónoma de México. Cd Mx., México. 75 pp.

Ulloa, M. and R. T. Hanlin. 2012. Illustrated dictionary of mycology. 2nd ed. APS Press. St. Paul, USA. 762 pp. 